Technical Report

\title{
Effect of Natural Stabilizer on Gelatinization Property of Etherified Tapioca Starch
}

\author{
Shigeyoshi FuJII* \\ * Ajinomoto General Foods, Inc, Central Research Laboratories, 6410, Minami \\ Tamagaki-cho, Suzuka-shi, Mie 513
}

\begin{abstract}
The gelatinization property of etherified tapioca starch was investigated using a DSC, a photomicrograph and a Brabender Viskograph. The effects of the stabilizers (gelatin, locust bean gum, xanthan gum, carrageenan, guar gum, low methoxyl pectin and tamarind gum) on Viskogram of etherified tapioca starch was also studied. The results showed that addition of a stabilizer influenced the Viskogram of the starch. Guar gum or locust bean gum raised the viscosity of the starch after the temperature reached $95^{\circ} \mathrm{C}$. All other stabilizers decreased the viscosity. Moreover all the stabilizers except guar gum raised the temperature at which the viscosity initially increased. Stabilizers with a high water-binding or gelling property were expected to suppress the degree of gelatinization. The investigation on the interaction between gelatin and etherified tapioca starch showed that gelatin promoted gelatinization at lower starch level while gelatin suppressed gelatinization at higher starch level.
\end{abstract}

It is well known that modified food starch is extremely stable when used in freeze-thaw recycling ${ }^{\text {) }}$. In particular, tapioca starch is resistent to retrogradation due to low content of amylose and etherified one is used to improve the storage stability and texture characteristics $^{2)}$ in ice cream products. Frozen pudding applying etherified tapioca starch has shown excellent storage stability and texture ${ }^{33}$.

It is essential to know the basic properties of starch for its effective application to foods. For example, in order to optimize the process or cooking conditions, it is necessary to evaluate the gelatinization property. However, relatively little technological data on etherified tapioca starch is available to food industries. It is not sufficient, however, to simply discuss the starch property since food products are consisted of rather complicated system. In other words, the interaction of the starch with other food ingredients should be studied.

The combination of a starch and a stabilizer( ${ }^{() \sim 6)}$ is common in desserts. However, it is generally said that hydrocolloids inhibit gelatinization in a lower content of water (40 to $60 \%)^{7}$. It is also known that monoglycerides combine with the surface of starch particles and inhibit the degree of gelatinization ${ }^{8)}$. Moreover, monoglycerides and starch amylose form a complex, resulting in the suppression of the gelatinization ${ }^{8)}$. This suggests that a stabilizer with a high water-binding property or high affinity for starch will inhibit starch gelatinization. In applying stabilizer to starch-based products, it is important to know the effect of stabilizer on the gelatinization property of starch. Previous report ${ }^{9)}$, where the interaction of stabilizers with starch was discussed by only looking at the results of starch particle size measurements, also suggested the importance of studying the interaction of starch with stabilizers. This interaction was mainly studied in a frozen pudding formula that included many other food ingredients, and the starch level studied was also lower than the general application level to dessert products.

The main objectives here are to study the 
gelatinization property of etherified tapioca starch and its interaction with natural stabilizer.

\section{Materials and Methods}

\section{Materials}

Etherified tapioca starch was purchased from Oji National Co.. Seven natural stabilizers employed in this study are gelatin (250 Bloom value) (GE), locust bean gum (Saneigen FFI Co.) (LBG), xanthan gum (Dainippon Pharmaceutical Co.) (XG), iota-carrageenan (FMC Co.) (CRG), guar gum (Saneigen FFI Co.) (GG), low methoxyl pectin (Sansho Co.) (LMP) and tamarind gum (Dainippon Pharmaceutical Co.) (TG).

\section{Method}

Rigaku Denki's differential scanning calorimeter (DSC-8230) was used to analyze the gelatinization property. An aluminum (Al) pan filled with $\mathrm{Al}_{2} \mathrm{O}_{3}$ was used as the control. Two hundred micrograms of the starch was put into DSC pans. Deionized water was added to bring the total weight within a range of 9-10 mg (excess moisture content). The pans were hermetically sealed, and heated on a DSC from $30^{\circ}$ to $150^{\circ} \mathrm{C}$ at 1 to $10^{\circ} \mathrm{C} / \mathrm{min}$. The results were analyzed using a thermal analyzer (Rigaku TAS 100). The amount of energy needed to complete gelatinization was determined by integrating the curves obtained from plotting DSC test results. In order to simulate the degree of gelatinization during actual cooking process, the starch solution was heated to the targeted temperature at a increasing rate of $5^{\circ} \mathrm{C} / \mathrm{min}$ in a heating vessel and sampled for analysis. The degree of gelatinization was calculated by dividing the curve integration for an untreated sample into the difference between the curve integrations for untreated and test sample.

To study changes in the starch particle size during the cooking process, the diameters of 100 starch particles were measured using a photomicrograph and an average was taken.

The change in the viscosity of the etherified tapioca starch during the cooking process was measured using a Brabender Viskograph-E.
The methodology was based on the general procedure described in the literature ${ }^{10}$. The effect of stabilizer on the gelatinization of etherified tapioca starch was investigated using Viskograph. Each stabilizer $(0.1 \%$ of total weight basis) was added to the etherified tapioca solution in Viskograph.

\section{Results and Discussion}

\section{Gelatinization property of etherified tapioca starch}

Fig. 1 shows the relationship between the gelatinization temperature and heating rate. Starting temperature, peak temperature and conclusion temperature of gelatinization were obtained from the DSC peak based on the general procedure ${ }^{11)}$. It is clear that the temperature of starch gelatinization depends on the heating rate. At a rate of $1^{\circ} \mathrm{C} / \mathrm{min}$, gelatinization started at $71^{\circ} \mathrm{C}$ and concluded at $86^{\circ} \mathrm{C}$. However, at a rate of $10^{\circ} \mathrm{C} / \mathrm{min}$, gelatinization started at $100^{\circ} \mathrm{C}$ and concluded at $126^{\circ} \mathrm{C}$. This difference might occur because the rate of gelatinization could not follow the heating rate. The endothermic heat $(\Delta \mathrm{H})$ value show no definite dependence on the heating rate. The average value of $\Delta \mathrm{H}$ with standard deviations were estimated to be $3.8 \pm 0.4 \mathrm{cal} / \mathrm{g}$. Fig. 2 shows changes in the starch gelatinization ratio when the heating rate varied. The degree of gelatinization at each heating rate is clearly indicated in this figure and it depended on heating rate. The starch solution was

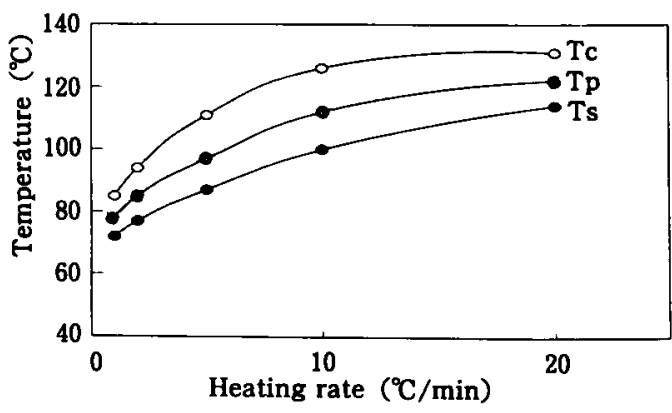

Fig. 1 Effect of heating rate on gelatinization temperature of etherified tapioca starch Ts, starting temperature : $\mathrm{Tp}$, peak temperature ; Tc, conclusion temperature. 
heated to the targeted temperature, kept for a certain time in a heating vessel, and analyzed using DSC. Fig. 3 indicates the relationship between the degree of gelatinization and cooking temperature. As can be seen in Fig. 3, 50 seconds cooking at $95^{\circ} \mathrm{C}$ was sufficient to ensure 100\% gelatinization. Fig. 4 indicates the relationship between the starch particle size and cooking temperature during the cooking procedure at a heating rate of $5^{\circ} \mathrm{C} / \mathrm{min}$. Averaged particle size of raw etherified tapioca starch ranged between 9 and $25 \mu \mathrm{m}$. The cooking process enlarged the particle size to between 20 and $90 \mu \mathrm{m}$. Relatively little particle disruption was observed via photomicrograph analysis.

Fig. 5 shows the Brabender Viskogram with

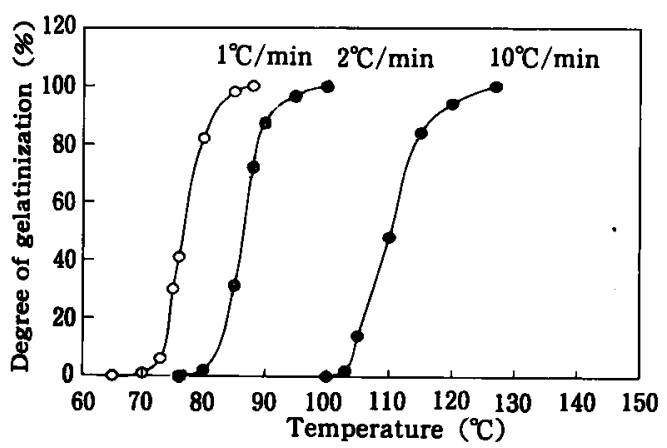

Fig. 2 Change in degree of gelatinization at different heating rate

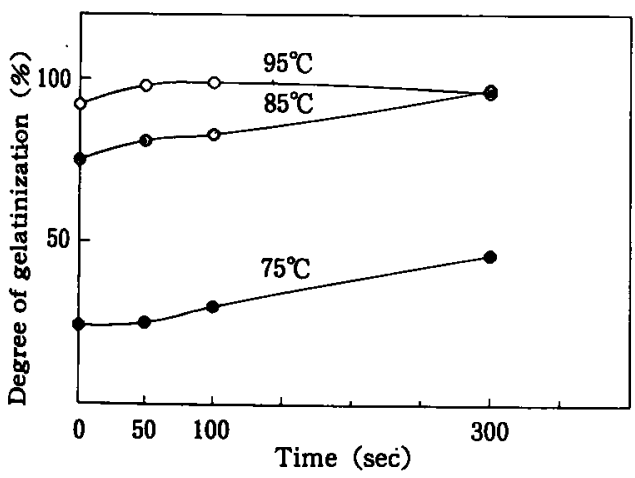

Fig. 3 Relation between degree of gelatinization and cooking time

Numerals on curves represent the cooking temperature

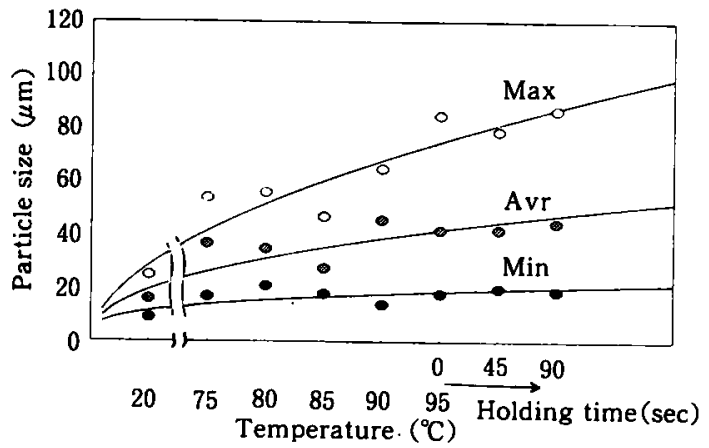

Fig. 4 Change of etherified tapioca starch particle size during cooking process Max, maximum starch particle size; Avr, averaged starch particle size ; Min, minimum starch particle size.

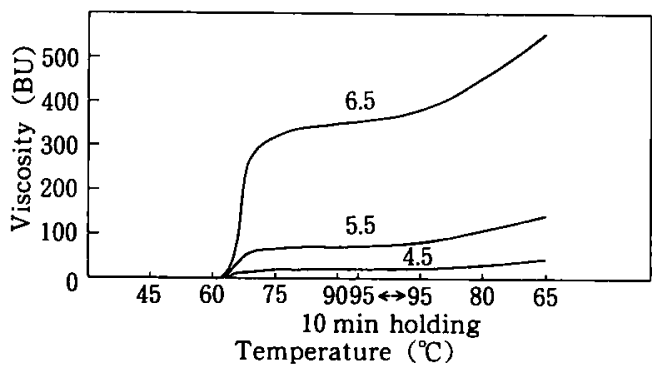

Fig. 5 Viskograms of etherified tapioca starch at various concentrations

Numerals on curves represent the concentration in \%. Starch solution was heated to $95^{\circ} \mathrm{C}$, held for $10 \mathrm{~min}$ and cooled down. $\mathrm{BU}$ : Brabender unit.

a different level of starch concentration. Regardless of the etherified tapioca starch concentration there was no breakdown after cooking in any case. Starch granule observation in the photomicrograph supported these results, indicating that etherified tapioca starch is very stable and resistent to both physical and heat shocks. The temperature at which the viscosity started to increase was raised when the starch level was reduced. This was consistent with the general case of starch gelatinization ${ }^{12}$. Raw tapioca starch broke down after cooking and did not remain stable when subjected to physical shock ${ }^{13)}$. Etherification of tapioca starch was found to be effective for stabiliza- 
tion.

2. Effect of natural stabilizers on the gelatinization of etherified tapioca starch

Brabender analysis is a very practical way to discuss the gelatinization property during the cooking process, since food products are often manufactured by a complex process and the viscosity of the product is extremely important in designing the processing equipment. The effects of natural stabilizers on the Viskogram of etherified tapioca starch were investigated. The viscosity change range was narrow when the starch level was below $5.5 \%$, and it was difficult to study the influence of a stabilizer on the Viskogram. Therefore, the starch level was set at $6.5 \%$ in later experiments. The addition level of stabilizer was fixed at $0.1 \%$ of the total weight basis, which was presumed to be a normal level for many food products. The Viskogram is shown in Fig. 6.

The addition of GG increased the viscosity significantly and showed a slight breakdown when held for $10 \mathrm{~min}$ at a temperature of $95^{\circ} \mathrm{C}$. Other stabilizers exhibited no breakdown when the temperature reached $95^{\circ} \mathrm{C}$. In the GG Viskogram, a two-stage viscosity increase was observed during the cooking process.
The Viskogram shows the change in viscosity during the starch cooking process, and reflects the starch particle's swelling and/or disruption. The temperature at which the viscosity initially increases is determined by starch swelling and the contact between particles. Breakdown resulting from starch particle disruption is generally observed in the final cooking stage. The synergitic effect of GG and starch activated the contact between particles and increased the viscosity, which, in turn, caused granule disruption. This is because GG galactomannan chain was extended during dissolution by the heating process, and as a result, damaged the starch surface physically. A photomicrograph of cooked slurry including GG revealed starch particle disruption. Such a disruption could explain the breakdown that was observed in the Viskogram.

This study also showed that adding XG to starch decreased the viscosity after the temperature reached $95^{\circ} \mathrm{C}$. KuHM et al. ${ }^{14)}$ reported that cooperative linkage of $\beta-1,4-D-$ glucanchains of XG with $\alpha-1,4-D$-glucan chains of starch takes place, leading to the inhibition of gelatinization. It is presumed that XG combines with starch via hydrogen bonding, and

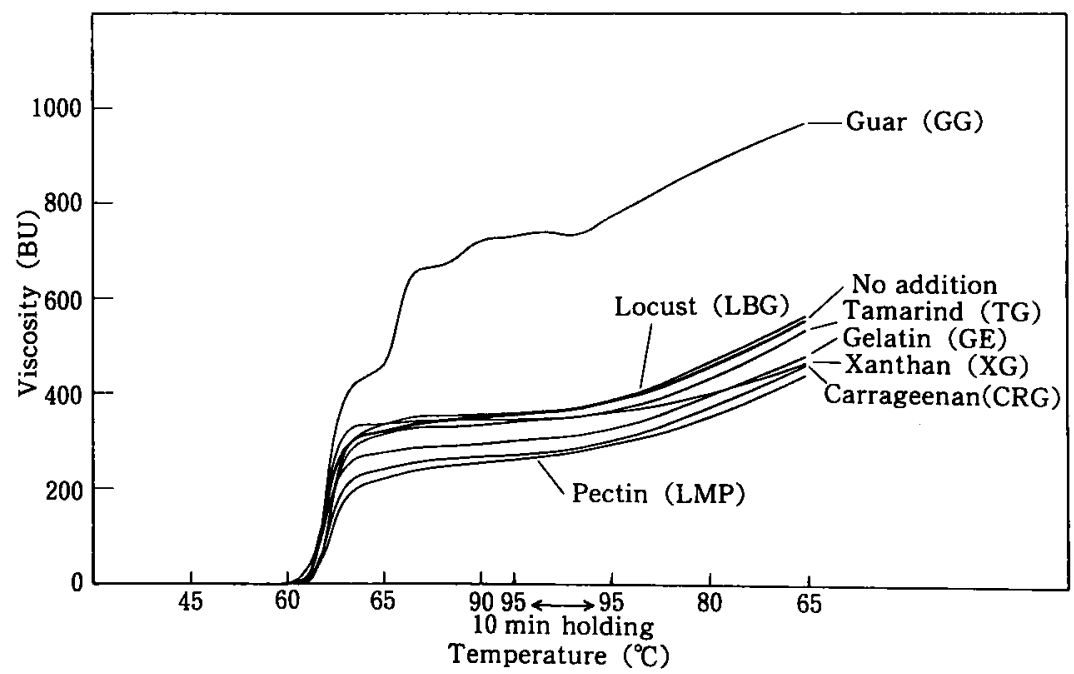

Fig. 6 Effects of stabilizer on Viskogram of etherified tapioca starch Starch solution was heated to $95^{\circ} \mathrm{C}$, held for $10 \mathrm{~min}$ and cooled down. BU : Brabender unit. 
thereby inhibits the gelatinization.

Adding LMP to etherified tapioca starch significantly inhibited the gelatinization. High solubility of LMP is presumed to restrict the moisture for starch gelatinization. DUXBURY ${ }^{5)}$ reported that CRG revealed a synergitic effect with starch. However, no increase of viscosity was observed in the present system.

Gelatin also suppressed gelatinization. HiRata and Kugimiya ${ }^{16)}$ studied the effect of azuki bean protein on azuki bean starch, determining that protein coagulation resulting from heat treatment and the thickness of the cell walls inhibited the gelatinization process. Gelatin, however, is a protein-based gelling agent, which has low coagulation property. Therefore, the suppression cannot be explained by such a physical phenomenon. Like other gums, GE's water-binding property affects the degree of gelatinization. As WATSON and JoHNSON ${ }^{15)}$ pointed out, GE having great affinity for water may compete for available moisture during gelatinization.
Gelatin is widely combined with starch in food processing ${ }^{17)}$ The additive effect of GE on gelatinization has previously been investigated by varying the addition level of $G E$ and starch. That study, however, only discussed the maximum viscosity. Here, the effect of $\mathrm{GE}$ on gelatinization was examined by comparing Viskograms (Fig. 7). These Viskograms indicated that the degree of viscosity increase was significantly suppressed at the initial stage of gelatinization in higher starch concentration. The viscosity, after a temperature was reached at $95^{\circ} \mathrm{C}$, was reduced as the amount of GE added increased. On the other hand, in lower concentrations of starch, GE tended to increase the viscosity. This is consistent with the results reported by SANDSTEDT and $A$ Авот ${ }^{17}$. It is clear that the influence of GE on gelatinization will differ depending on starch concentration. This indicates that the degree of affinity of GE and that of etherified tapioca starch for water may be altered by varying the amount of water of the system.

Starch gelatinization was influenced by

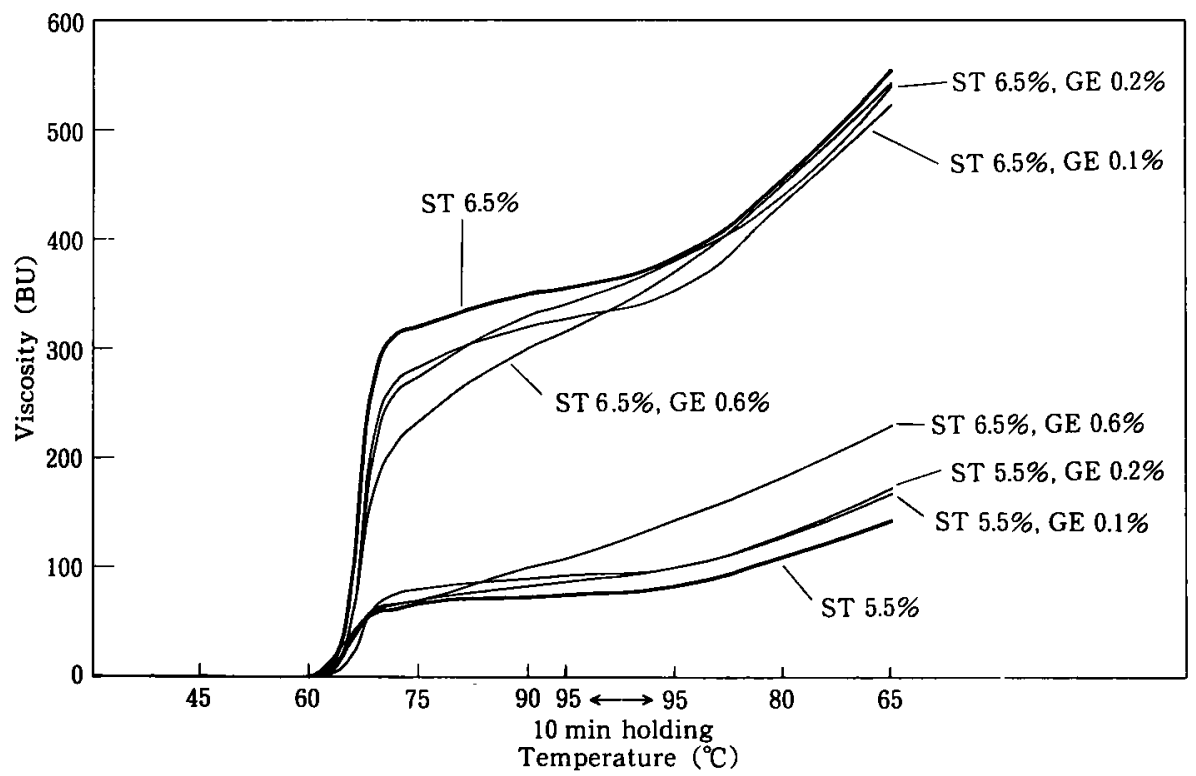

Fig. 7 Effect of gelatin addition on Viskograms of etherified tapioca starch

Starch solution was heated to $95^{\circ} \mathrm{C}$, held for $10 \mathrm{~min}$ and cooled down. Numerals represent concentration.

BU, Brabender unit ; ST, etherified tapioca starch ; GE, gelatin. 
many factors including the type of stabilizer used, and the concentrations of starch and stabilizer. Further study of the interaction between starches and stabilizers in the food complex would be required in the future.

Acknowledgements : The author would like to thank Dr. M. Ninmura for his useful suggestions and encouragement to improve this manuscript.

\section{Reference}

1) Kokura, T.: Denpun Kagaku Hand Book, NaKamuRA, M. and SuzUKi, S. ed. (Asakura Shoten, Tokyo), p.511 (1977).

2) D'ERCOLE, A.D. : US Patent 3, 669, 687 (1972).

3) FujII, S., Yokoyama, S. and Sakaguchi, M. : Jap. Patent Dis. Hei 1-196261 (1989).

4) OHAshI, S. : Anteizai to sono Riyo Gijutsu, (Eisei Gijutsu Kai, Tokyo), p. 350 (1981).

5) DuXbury, D.D. : Food Processing, 47, 48 (1986).

6) RAPAILle, A., VANHEMELRIJCK and MOYLER, J. : Dairy Industries International, 53, 23 (1988).

7) HIZUKURI, S : Shokuhin Kogyo, 12 (2), 89 (1969).

8) NARA, S., MaEdA, I. and Tsuzino, T. :,Nogei Kagaku Kaishi, 38, 356 (1964).

9) FuJil, S.: Nippon Shokuhin Kogtyo Gakkaishi, 41, 440 (1994).

10) Gото, F. : Denpun Kagaku Hand Book, NAKAMURA, M. and SuzuKI, S. ed. (Asakura Shoten, Tokyo), p. 227 (1977).

11) Takahashi, K., ShiraI, K., Wada, K. and Kawamura, A. : Nogei Kagaku Kaishi, 52, 201 (1978).

12) Hirata, T. and Kugimiya, M. : Nippon Shokuhin Kogyo Gakkaishi, 32, 35 (1985).

13) HizUKuRI, S.: Denpun Kagaku Hand Book, NAKAmURA, M. and Suzuki, S. ed. (Asakura shoten, Tokyo), p. 37 (1977).

14) KuHN, M., ElSNER, G. and Graber, S. : Starch, 41, 467 (1989).
15) Watson, C. and Johnson, J.A. : J. Food Sci., 30, 450 (1965).

16) Inaba, H., Hatanaka, Y., Kageyama, O., Matsumura, Y. and Mori, T. : Nippon Shokuhin Kogyo Gakkaishi, 36, 884 (1984).

17) SAndstedt, R.M. and Abbot, R.C. : Cereal Science Today, 9,13 (1964).

(Received Jan. 18, 1994)

\section{エーテル架橎タビオカ激粉の糊化に及ぼす 天然安定剤の影斐}

藤井繁佳*

*味の素ゼネラルフーツ(株)

（宁513 三重県鈴鹿市南玉垣町 6410 )

エーテル架橋タピオカ激粉の糊化特性を示差熱分析、 顕微鏡写真及びブラベンダービスコグラフにて調查し た．更に，当該㴬粉のビスコグラムに及ぼす天然安定郕 の影響についてもあわせて検討した，天然安定殽として 代表的なぜラチン，ローカストビーンガム，キサンタン ガム，カラギーナン，グアーガム，ペクチンとタマリン ドガムを対象とした，その結果, 天然安定郕はエーテル 架橋夕ピオカ湍粉のビスコグラムを変化させることが明 らかとなった，グアーガムとローカストビーンガムは， $95^{\circ} \mathrm{C}$ に達した後の粘度を上昇させた。 他の天然安定棛は 逆に粘度を低減させた，また，グアーガムを除く他の安 定剤はエーテル架橋夕ピオカ政粉の糊化開始温度を，上 昇させ糊化の抑制を示唆した，保水性あるいはゲル形成 性が高い安定剤ほど、エーテル架橋タピオカ測粉が糊化 する際に必要とする水分を制限しているもの之推察され た。ゼラチンとエーテル架橋夕ピオカ潄粉との交互作用 をビスコグラム上で検討したところ，激粉飸度が高いと きは，ゼラチンの添加は糊化を抑制し，澱粉濃度が低い 時には，糊化を促進するという興味ある知見を得た。 